\title{
Higher Education students from health and non-health subject areas: aspects of oral health
}

\author{
Universitários da área de saúde e não \\ saúde: aspectos de saúde bucal
}

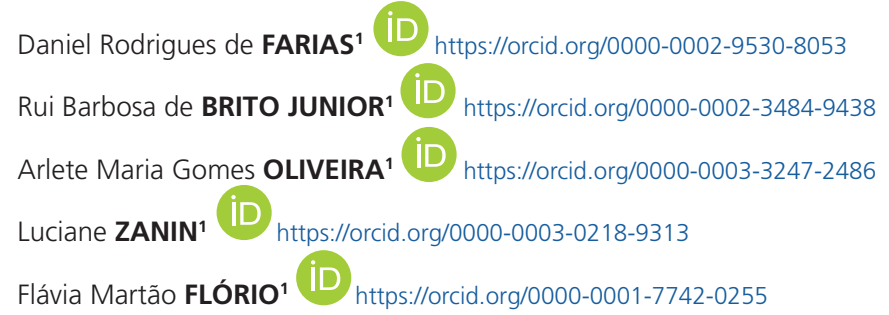

\section{ABSTRACT}

Objective: To evaluate whether the area of study of undergraduate students influences oral health knowledge, attitudes and practices, in addition to the use of dental services, self-reported oral morbidity, self-perception and impacts of oral health. Methods: A cross-sectional study was performed, with a probabilistic sample of 681 students from the second semester of a Higher Education Institution, who were allocated into Health $(\mathrm{H} ; \mathrm{n}=347)$ and Non-Health $(\mathrm{NH} ; \mathrm{n}=334)$ groups, and answered a questionnaire encompassing their sociodemographic profile and aspects of oral health. Data were analyzed by Fisher's Chi-Square/Exact Test ( $\alpha=5 \%$ ). Results: The majority of students were female $(H=70.0 \%, N H=56.9 \%, p=0.0004)$, single $(H=82.7 \%, N H=76.0 \%, p=0.0429)$ and did not work $(\mathrm{H}=30.5 \%, \mathrm{NH}=37.7 \%, \mathrm{p}=0.0482)$. The groups differed in terms of receiving oral health guidelines from the media ( $\mathrm{H}=19.9 \%, \mathrm{NH}=13.8 \%, \mathrm{p}=0.0333$ ) or from other health professionals $(\mathrm{H}=25.6 \%, \mathrm{NH}=13.2 \%, \mathrm{p}<0.0001)$. Regarding the reasons for their most recent dental appointment, in the Health group "treatment" (42.9\%) and "pain" (6.9\%) prevailed, while for the Non-Health group "review, prevention or check-up" $(41,9 \%)$ and "extraction" $(8.1 \%)$ ( $p=0.0169)$ were the most prevalent. The Health group was more satisfied with their oral health, with less frequent reports of a self-perception of bad breath $(\mathrm{H}=30.3 \%, \mathrm{NH}=38.3 \%, \mathrm{p}=0.0483)$. There was no association between self-perception and impacts on oral health ( $p>0.05)$. Conclusion: The groups differed regarding the source of information on oral health, the reason for seeking and type of treatment, and the self-perception of bad breath, with the Health group reporting greater satisfaction with their oral health.

Indexing terms: Knowledge. Habits. Oral Health.

\section{RESUMO}

Objetivo: Avaliar se a área de graduação influencia nos aspectos de saúde bucal avaliados. Métodos: Estudo transversal com amostra probabilística de 681 estudantes do $2^{\circ}$ período de uma Instituição de Ensino Superior foi alocada nos grupos Saúde (S; n=347) e Não Saúde (NS; $n=334$ ) e respondeu questionário englobando perfil sociodemográfico e aspectos de saúde bucal. Os dados foram analisados

$\boldsymbol{\nabla} \boldsymbol{\nabla} \boldsymbol{\nabla}$

1 Faculdade São Leopoldo Mandic, Instituto de Pesquisa São Leopoldo Mandic, Curso de Odontologia, Programa de Pós-graduação em Saúde Coletiva. Rua José Rocha Junqueira, 13, Swift, 13045-755, Campinas, SP, Brasil. Correspondence to: DR FARIAS. E-mail: <drfphb@hotmail.com>.

$\boldsymbol{v} \boldsymbol{v}$

How to cite this article

Farias DR, Brito Junior RB, Oliveira AMG, Zanin L, Flório FM. Higher Education students from health and non-health subject areas: aspects of oral health. RGO, Rev Gaúch Odontol. 2021;69:e2021014. http://dx.doi.org/10.1590/1981-86372021001420190135 
pelos Testes Qui-quadrado/Exato de Fisher ( $\alpha=5 \%)$. Resultados: A maioria dos estudantes era de sexo feminino (S=70,0\%; NS=56,9\%; $p=0,0004)$, solteiro ( $S=82,7 \% ; N S=76,0 \% ; p=0,0429)$ e não trabalha $(S=30,5 \% ; N S=37,7 \% ; p=0,0482)$. Os grupos diferiram quanto a ter recebido orientações sobre saúde bucal pela mídia $(S=19,9 \% ; N S=13,8 \% ; p=0,0333)$ ou por outros profissionais da saúde $(S=25,6 \% ; N S=13,2 \% ; p<0,0001)$. Quanto aos motivos para a última consulta odontológica, prevaleceu para o grupo $S$ "tratamento" (42,9\%) e "dor" (6,9\%) enquanto para o grupo NS "revisão, prevenção ou check-up" (41,9\%) e "extração" (8,1\%) (p=0,0169). 0 grupo $S$ mostrou-se mais satisfeito em relação à saúde bucal, com menor frequência de relatos sobre autopercepção de mau hálito ( $S=30,3 \% ; N S=38,3 \% ; p=0,0483$ ). Não houve associação da autopercepção e impactos em saúde bucal ( $p>0,05)$. Conclusão: Os grupos diferiram quanto à fonte de informações sobre saúde bucal, razão da busca e tipo de tratamento, e autopercepção de mau hálito, com o grupo Saúde referindo maior satisfação com sua saúde bucal.

Termos de indexação: Conhecimento. Hábito. Saúde bucal.

\section{INTRODUCTION}

University students are considered a vulnerable group for oral pathologies, with greater treatment needs, due to a lack of oral health education, fear of dental procedures and the adoption of habits that negatively affect the oral tissues, such as alcohol consumption, smoking and a high intake of sugar and soft drinks [1-3]. Oral diseases result in pain, tooth loss, low self-esteem and absenteeism, with negative repercussions for academic performance [4].

Studies that assess the knowledge, attitudes, practices, behavior and self-perception of university students in relation to their oral health have found greater levels of knowledge and positive habits among women, students from public institutions, and those taking courses in the area of health, especially dentistry [3-8]. Other studies, meanwhile, have identified limited oral hygiene practices among students from the areas of health, the humanities and the sciences, with such individuals reporting dissatisfaction with their mouths and teeth, and seeking dental care only in case of severe pain or discomfort [9-11].

Identifying the influence of the area of study on these variables enables the needs of students, especially from areas other than health, to be evaluated, supporting strategies aimed at disease prevention and health promotion $[1,9,10]$. It is important to evaluate hygiene habits among students of health-related subjects, as these individuals are the medical professionals of the future, and will directly influence their patients either through the guidance they provide or as models to be followed [12].

Traditionally, literature has sought to evaluate the knowledge, habits and attitudes in oral health of students of health-related subjects, and expanding the discussion to include the analysis of others, involving students from other areas, represents a new trend. Therefore, the aim of the present study was to evaluate whether the area of study of undergraduate students affects their knowledge, attitudes and practices in oral health, use of dental services, reported oral morbidity, self-perception and impacts on oral health.

\section{METHODS}

The study was conducted according to the precepts determined by National Health Council Resolution 466/12 of the Ministry of Health and was approved by the Research Ethics Committee of the São Leopoldo Mandic School of Dentistry and Center for Dental Research under number 1.862.343/2016 (CAAE 62361416.6.0000.5374).

An observational, cross-sectional study, with an analytical approach and a quantitative focus, was carried out in a private Higher Education Institution (HEI) in the city of Parnaíba, the second most populous city in the state of Piauí, and which has been established as a university center in recent years. The respective HEl offered, at the time of data collection (2016), seven (07) courses in the area of health (Nursing, Nutrition, Physiotherapy, Physical Education, Aesthetics and Cosmetics, Pharmacy and Psychology), and eight (08) courses in the areas of the humanities and sciences (Civil Engineering, Architecture, Law, Pedagogy, Administration, Accounting Sciences, Information Systems and Social Work), which in the present article are referred to as "non-health" courses. There were a total of 3,829 students enrolled at the HEl in the period in which the study was conducted (between August and December 2016).

The participants in the study were students who were enrolled and attended class regularly in the 2 nd semester of the courses offered by the college, as this period had the highest absolute frequency of students $(n=1,184)$ and was the only one that offered active classes in all courses. We excluded those students who were not present in the institution on the days when 
the questionnaire was applied, on two opportunities (corresponding to alternate days of an academic week), and incomplete questionnaires.

For the sample calculation, students enrolled in courses from the Health $(\mathrm{H})$ and Non-Health $(\mathrm{NH})$ blocks were considered, based on a prevalence of $50 \%$, a value that allows the highest degree of variance and corresponds to the minimum accepted size for the sample to be representative of the population. Considering a 95\% confidence level, 10\% accuracy, a design effect (deff) of 1.5 [13], a non-response rate of $10 \%$ and a finite population adjustment based on the total number of students enrolled in the 2nd semester, the resulting minimum sample size was 309 students from the H Block and 333 students from the $\mathrm{NH}$ block.

To allocate the individuals in the sample, the academic secretary of the college was asked to list the classes with the names of the students in alphabetical order. These were then added together to comprise a single list for the Health Block, and another for the Non-health Block. In each list, the students were numbered sequentially and independently of each other.

To choose the sample elements, a systematic random sample technique was used, with the sample and student range determined based on the start of the randomization. Subsequent participants were obtained by adding the sequential number of the previous student to the sample range, according to the recommended technique [13].

Data collection occurred in the facilities of the college itself, during class times, in the morning and evenings, after a pilot test with ten students who did not participate in the sample, for observation and adjustment of the questionnaire based on any queries that arose.

Initially, the students selected from the draw were contacted and taken to their own classrooms where, after signing the Informed Consent Form, they received a self-administered questionnaire consisting of four blocks of questions, as described below:

- BLOCK 1: Sociodemographic profile - sex, age, marital status, undergraduate course, period enrolled, and whether the student worked, with a description of the workload of any such labor.
- BLOCK 2: Knowledge, attitudes and practices of oral health - grouped questions used in Brazilian and international studies on the theme $[3-5,14]$, through which the interviewees selected the option that best suited their knowledge and behavior in relation to oral health.

- BLOCK 3: Use of dental services and selfreported oral morbidity - in this section the oral morbidity reported by the students was evaluated and how they used dental services, based on questions taken from the instrument employed in the Ministry of Health National Oral Health Survey (SB Brazil Project 2010) [13].

- BLOCK 4: Self-perception and impacts on oral health - this block included questions about how the oral health/disease process was perceived at an individual level, using questions from the SB Brazil Project 2010 [13,15].

The researcher remained in the room during the application of the instrument, for possible clarification of its content, but did not interfere with the participants' answers. After completing the questionnaire, each student deposited their questionnaire in a communal envelope, preserving their anonymity.

Data analysis was performed based on the Health and Non-Health blocks, and the questions were categorized using the sample median in order to study the association between the response and the blocks. To verify the association between the variables, logistic regression analysis was performed, using Fisher's chi-square and exact tests, performed in the SAS* program and considering a significance level of $5 \%$.

\section{RESULTS}

The study included 681 students, 347 from the Health block and 334 from the Non-Health block.

The analysis of the association between the area of study and the responses related to personal data (table 1) revealed a significant association $(p<0.05)$ between the frequencies of sex, marital status and the fact that the student did not work, and the area of study. In the area of health, most students were female, reported that they were single, and did not work outside their courses.

\footnotetext{
$\boldsymbol{\nabla v} \nabla$

* SAS Institute Inc., Cary, NC, USA, Release 9.2, 2010
} 
Table 1. Associations between responses to questions on Sociodemographic Profile and area of study (health and non-health).

\begin{tabular}{|c|c|c|c|c|c|}
\hline Question & Category & Total & Health & Non-Health & $\mathrm{p}$-value \\
\hline Sex & Male & $248(36.4 \%)$ & $104(30.0 \%)$ & $144(43.1 \%)$ & \\
\hline \multirow{2}{*}{ Age } & Up to 25 years old & $506(74.3 \%)$ & $263(75.8 \%)$ & $243(72.8 \%)$ & 0.3644 \\
\hline & Over 25 years & $175(25.7 \%)$ & $84(24.2 \%)$ & $91(27.2 \%)$ & \\
\hline Marital Status & Partner & $131(19.2 \%)$ & $58(16.7 \%)$ & $73(21.9 \%)$ & \\
\hline \multirow{2}{*}{ Do you work outside the course? } & No & $449(65.9 \%)$ & $241(69.5 \%)$ & $208(62.3 \%)$ & 0.0482 \\
\hline & Yes & $232(34.1 \%)$ & $106(30.5 \%)$ & $126(37.7 \%)$ & \\
\hline Weekly workload & Up to 40 hours & $173(74.6 \%)$ & $80(75.5 \%)$ & $93(73.8 \%)$ & 0.7721 \\
\hline
\end{tabular}

Regarding the knowledge, attitudes and practices of the students, there was a significant association $(p<0.05)$ between the study group and the source of guidance on oral health, represented by the media and other health professionals (table 2), with higher frequencies, in both situations, among university students in the Health group.

The other questions related to Block 2 did not present a significant association with the study group

Table 2. Associations between responses to questions relating to knowledge, attitudes and practices in oral health and area of study.

\begin{tabular}{|c|c|c|c|c|c|}
\hline Question & Category & Total & Health & Non-Health & p-value \\
\hline \multirow{2}{*}{ Oral health considered an integral part of general health } & No & $3(0.4 \%)$ & $2(0.6 \%)$ & $1(0.3 \%)$ & 1.000 \\
\hline & Yes & $678(99.6 \%)$ & $345(99.4 \%)$ & $333(99.7 \%)$ & \\
\hline \multirow[t]{2}{*}{ Received oral health guidelines } & No & $32(4.7 \%)$ & $13(3.7 \%)$ & $19(5.7 \%)$ & 0.2312 \\
\hline & Yes & $649(95.3 \%)$ & $334(96.3 \%)$ & $315(94.3 \%)$ & \\
\hline \multirow{2}{*}{ Received guidance from the dentist } & No & $171(25.1 \%)$ & $92(26.5 \%)$ & $79(23.7 \%)$ & 0.3895 \\
\hline & Yes & $510(74.9 \%)$ & $255(73.5 \%)$ & $255(76.3 \%)$ & \\
\hline \multirow[t]{2}{*}{ Received academic guidance } & No & $639(93.8 \%)$ & $325(93.7 \%)$ & $314(94.0 \%)$ & 0.8486 \\
\hline & Yes & $42(6.2 \%)$ & $22(6.3 \%)$ & $20(6.0 \%)$ & \\
\hline \multirow[t]{2}{*}{ Received guidance from the media } & No & $566(83.1 \%)$ & $278(80.1 \%)$ & $288(86.2 \%)$ & 0.0333 \\
\hline & Yes & $115(16.9 \%)$ & $69(19.9 \%)$ & $46(13.8 \%)$ & \\
\hline \multirow[t]{2}{*}{ Received family guidance } & No & $506(74.3 \%)$ & $253(72.9 \%)$ & $253(75.7 \%)$ & 0.3969 \\
\hline & Yes & $175(25.7 \%)$ & $94(27.1 \%)$ & $81(24.3 \%)$ & \\
\hline \multirow[t]{2}{*}{ Received guidance from other health professionals } & No & $548(80.5 \%)$ & $258(74.4 \%)$ & $290(86.8 \%)$ & $<0.0001$ \\
\hline & Yes & $133(19.5 \%)$ & $89(25.6 \%)$ & $44(13.2 \%)$ & \\
\hline \multirow{2}{*}{ Daily brushing frequency } & Up to 3 times & $472(69.3 \%)$ & $241(69.5 \%)$ & $231(69.2 \%)$ & 0.9345 \\
\hline & More than 3 times & $209(30.7 \%)$ & $106(30.5 \%)$ & $103(30.8 \%)$ & \\
\hline \multirow{2}{*}{ Flossing } & No & $93(13.7 \%)$ & $47(13.5 \%)$ & $46(13.8 \%)$ & 0.9310 \\
\hline & Yes & $588(86.3 \%)$ & $300(86.5 \%)$ & $288(86.2 \%)$ & \\
\hline \multirow{2}{*}{ Use of mouthwash } & No & $209(30.7 \%)$ & $99(28.5 \%)$ & $110(32.9 \%)$ & 0.2129 \\
\hline & Yes & $472(69.3 \%)$ & $248(71.5 \%)$ & $224(67.1 \%)$ & \\
\hline \multirow{3}{*}{ Tongue cleaning } & No & $18(2.6 \%)$ & $5(1.4 \%)$ & $13(3.9 \%)$ & 0.1361 \\
\hline & Yes (toothbrush) & $598(87.8 \%)$ & $308(88.8 \%)$ & $290(86.8 \%)$ & \\
\hline & Yes (tongue cleaner) & $65(9.5 \%)$ & $34(9.8 \%)$ & $31(9.3 \%)$ & \\
\hline
\end{tabular}


Table 2. Associations between responses to questions relating to knowledge, attitudes and practices in oral health and area of study.

\begin{tabular}{|c|c|c|c|c|c|}
\hline Question & Category & Total & Health & Non-Health & p-value \\
\hline \multirow{2}{*}{$\begin{array}{l}\text { Consumption of sweets, soft drinks, candies, chocolate or } \\
\text { cookies between meals }\end{array}$} & No & $100(14.7 \%)$ & $50(14.4 \%)$ & $50(15.0 \%)$ & \multirow[t]{2}{*}{0.8362} \\
\hline & Yes & $581(85.3 \%)$ & $297(85.6 \%)$ & $284(85.0 \%)$ & \\
\hline \multirow{2}{*}{$\begin{array}{l}\text { Opinion about types of food that determine the } \\
\text { appearance of caries }\end{array}$} & No & $87(12.8 \%)$ & $46(13.3 \%)$ & $41(12.3 \%)$ & \multirow[t]{2}{*}{0.7014} \\
\hline & Yes & $594(87.2 \%)$ & $301(86.7 \%)$ & $293(87.7 \%)$ & \\
\hline \multirow{2}{*}{ Smoker } & No & $647(95.0 \%)$ & $331(95.4 \%)$ & $316(94.6 \%)$ & \multirow[t]{2}{*}{0.6411} \\
\hline & Yes & $34(5.0 \%)$ & $16(4.6 \%)$ & $18(5.4 \%)$ & \\
\hline \multirow{3}{*}{ Time between toothbrush changes } & Up to 3 months & $497(73.0 \%)$ & $253(72.9 \%)$ & $244(73.1 \%)$ & \multirow[t]{3}{*}{0.7697} \\
\hline & More than 3 months & $87(12.8 \%)$ & $42(12.1 \%)$ & $45(13.5 \%)$ & \\
\hline & When damaged & $97(14.2 \%)$ & $52(15.0 \%)$ & $45(13.5 \%)$ & \\
\hline
\end{tabular}

( $p>0.05)$, and there were high frequencies of students who considered oral health to be an integral part of their general health, brushed their teeth up to three times a day and flossed. There was also a high consumption of sweets, soft drinks, candies, gum, chocolate or cookies between meals, as well as the intake of artificial juices more than twice a week. A small portion of the sample declared themselves to be smokers.

In the questions related to the use of dental services and reported oral morbidity, a significant association was observed between the area of study and the reason for the students' most recent dental appointments, as well as in relation to the perception of the presence of bad breath $(p<0.05)$ (table 3$)$. Among university students in the area of health, a higher frequency of "treatment" and "pain" responses was observed, as the reason for the most recent appointment, while among university students in other areas, there was a higher frequency of the answers "review, prevention or check-up" and also of "extraction". In addition, among students in the area of health, there was a lower frequency of the self-perception of bad breath.

Regarding self-perception and impact on oral health, the data showed no significant association ( $p>0.05$ ) with the area of study (table 4).

Table 3. Associations between responses to questions related to the use of dental services and self-reported oral morbidity. and area of study.

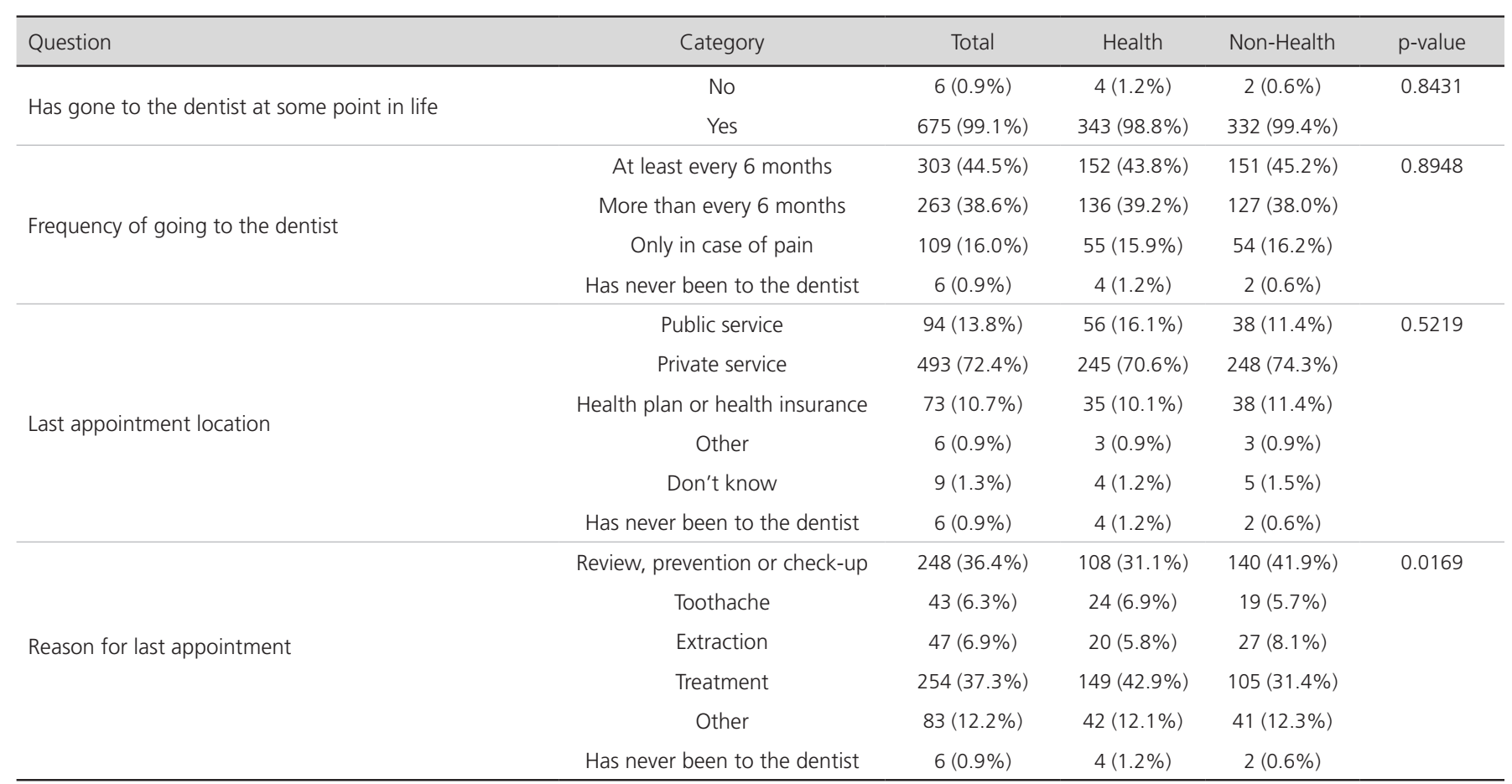


Table 3. Associations between responses to questions related to the use of dental services and self-reported oral morbidity. and area of study.

\begin{tabular}{|c|c|c|c|c|c|}
\hline Question & Category & Total & Health & Non-Health & p-value \\
\hline \multirow{2}{*}{$\begin{array}{l}\text { Presence of cavities that required restorations at } \\
\text { check-up appointments }\end{array}$} & Rarely & $412(60.5 \%)$ & $211(60.8 \%)$ & $201(60.2 \%)$ & \multirow{2}{*}{0.7691} \\
\hline & Has never been to the dentist & $6(0.9 \%)$ & $4(1.2 \%)$ & $2(0.6 \%)$ & \\
\hline Opinion on whether needs dental treatment today & No & $182(26.7 \%)$ & $99(28.5 \%)$ & $83(24.9 \%)$ & 0.2780 \\
\hline \multirow{2}{*}{ Toothache in the previous six months } & No & $503(73.9 \%)$ & $264(76.1 \%)$ & $239(71.6 \%)$ & \multirow[t]{2}{*}{0.1792} \\
\hline & Yes & $178(26.1 \%)$ & $83(23.9 \%)$ & $95(28.4 \%)$ & \\
\hline \multirow[b]{2}{*}{ Gingival bleeding when brushing } & No & $381(55.9 \%)$ & $207(59.7 \%)$ & $174(52.1 \%)$ & \multirow[t]{2}{*}{0.0793} \\
\hline & Sometimes & $285(41.9 \%)$ & $135(38.9 \%)$ & $150(44.9 \%)$ & \\
\hline Bad breath & Always & $4(0.6 \%)$ & $1(0.3 \%)$ & $3(0.9 \%)$ & 0.0483 \\
\hline
\end{tabular}

Table 4. Associations between questions related to self-perception and impacts on oral health, and area of study.

\begin{tabular}{|c|c|c|c|c|c|}
\hline Question & Category & Total & Health & Non-Health & p-value \\
\hline \multirow{5}{*}{ Satisfaction with teeth/mouth } & Very satisfied & $51(7.5 \%)$ & $28(8.1 \%)$ & $23(6.9 \%)$ & \multirow[t]{5}{*}{0.1897} \\
\hline & Satisfied & $286(42.0 \%)$ & $150(43.2 \%)$ & $136(40.7 \%)$ & \\
\hline & Neither satisfied nor dissatisfied & $225(33.0 \%)$ & $120(34.6 \%)$ & $105(31.4 \%)$ & \\
\hline & Dissatisfied & $105(15.4 \%)$ & $42(12.1 \%)$ & $63(18.9 \%)$ & \\
\hline & Very dissatisfied & $14(2.1 \%)$ & $7(2.0 \%)$ & $7(2.1 \%)$ & \\
\hline $\begin{array}{l}\text { Difficulty eating because of teeth or felt pain in teeth } \\
\text { when drinking cold or hot liquids }\end{array}$ & Yes & $329(48.3 \%)$ & $168(48.4 \%)$ & $161(48.2 \%)$ & 0.9560 \\
\hline \multirow{2}{*}{ Stopped playing sports because of teeth } & No & $671(98.5 \%)$ & $342(98.6 \%)$ & $329(98.5 \%)$ & \multirow[t]{2}{*}{1.000} \\
\hline & Yes & $10(1.5 \%)$ & $5(1.4 \%)$ & $5(1.5 \%)$ & \\
\hline Teeth caused discomfort when brushing & No & $631(92.7 \%)$ & $327(94.2 \%)$ & $304(91.0 \%)$ & 0.1075 \\
\hline \multirow{2}{*}{ Teeth cause embarrassment when smiling or speaking } & No & $542(79.6 \%)$ & $280(80.7 \%)$ & $262(78.4 \%)$ & \multirow[t]{2}{*}{0.4667} \\
\hline & Yes & $139(20.4 \%)$ & $67(19.3 \%)$ & $72(21.6 \%)$ & \\
\hline \multirow{2}{*}{ Teeth cause nervousness or irritation } & No & $548(80.5 \%)$ & $281(81.0 \%)$ & $267(79.9 \%)$ & \multirow[t]{2}{*}{0.7322} \\
\hline & Yes & $133(19.5 \%)$ & $66(19.0 \%)$ & $67(20.1 \%)$ & \\
\hline \multirow{2}{*}{$\begin{array}{l}\text { Teeth get in the way of studying/working or doing } \\
\text { schoolwork or chores }\end{array}$} & No & $659(96.8 \%)$ & $338(97.4 \%)$ & $321(96.1 \%)$ & \multirow[t]{2}{*}{0.3380} \\
\hline & Yes & $22(3.2 \%)$ & $9(2.6 \%)$ & $13(3.9 \%)$ & \\
\hline \multirow{2}{*}{$\begin{array}{l}\text { Stopped going out, having fun, going to parties, or } \\
\text { going for walks because of teeth }\end{array}$} & No & $657(96.5 \%)$ & $339(97.7 \%)$ & $318(95.2 \%)$ & \multirow[t]{2}{*}{0.0787} \\
\hline & Yes & $24(3.5 \%)$ & $8(2.3 \%)$ & $16(4.8 \%)$ & \\
\hline Haven't sleep or have sleep badly because of teeth & No & $585(85.9 \%)$ & $300(86.5 \%)$ & $285(85.3 \%)$ & 0.6729 \\
\hline
\end{tabular}




\section{DISCUSSION}

Higher education positively affects individuals, as the more educated the individual, the more likely they are to adopt good health practices [8]. In this sense, studies with university students allow the evaluation of the relationship between a higher level of education and attitudes and habits, which should be used to benefit both the individual and the progress of the society in which they will be professionally inserted, in addition to supporting changes that eliminate failings that may occur during training.

The predominance in the sample of full-time students, with a marital status of single, was due to the age group of the interviewees, as the majority were aged up to 25 years. The predominance of women can be associated with the greater contingent of the female sex in the Brazilian population in recent years and the increasing female participation in the labor market, which requires a greater need for qualifications. The microdata of the Higher Education Census has shown that in the last ten years the number of women entering, enrolled and concluding higher education was greater than that of men, mainly in private institutions [16].

In the present study, high frequencies of affirmative responses were observed for the receiving of instruction on oral health, more prevalently in the Health block, and especially in relation to the female sex, corroborating studies that highlight women as having greater knowledge and better habits in relation to oral health $[1-3,5,9,11$ 12]. The guidance from the media and other health professionals demonstrated an association with the study groups. Due to difficulties in accessing dental services in some regions, people often try to resolve their oral problems with the help other health professionals, while it is observed that the media, with its penetrative power in Brazilian society, provides an educational function, placed in the background by some dentists who prioritize the mechanistic and technical character of the profession [5].

Other findings of this block indicated a greater number of students who performed tooth hygiene three times a day, and the replacing of toothbrushes within three months, consistent with the recommendations of the American Dental Association (ADA), which recommends brushing with fluoridated toothpastes, routinely, at least twice a day, generating the effective removal of plaque, and changing one's toothbrush every three or four months $[17,18]$. Tongue cleaning (with a toothbrush) and flossing were reported by most participants, while the use of mouthwash was not mentioned as frequently, corroborating previous findings $[3-5,14]$. Smoking was reported by only $5 \%$ of the interviewees, contrasting with data from the Vigitel 2016 survey, which associated the reduction of smoking with increased schooling due to greater knowledge about the damage stemming from tobacco and its products [19].

The presence of practices that contradict knowledge of dental health was also noteworthy, as while the students stated that certain types of food were determinant for the appearance of caries, the frequency of those who reported the consumption of sugar, soft drinks or artificial juices between meals, and those who changed their toothbrush only when it was damaged, was in line with other studies $[3,5,20]$.

The analysis of data regarding the use of dental services and reported oral morbidity indicated that almost all the students reported having visited the dentist, with a significant association in relation to the reasons for their most recent appointment. The Health group presented a higher percentage of "treatment" and "pain" responses, while in the Non-Health group the reasons "review, prevention or check-up" and "extraction" were most prevalent. In previous studies, health students cited having regular check-ups [20] and review or control appointments $[3,4]$, while students from other areas responded with "treatment" [21] and "severe pain or discomfort" [22]. The results of the SB Brasil 2010 survey indicated that for the respective age group, the main reasons for dental appointments were "treatment" and "review or prevention", with a predominance of the answers "treatment" and "extractions" as age increases [23]. It is noticed that as the Health group had more individuals aged up to 25 years, they followed the regional and national trend of seeking treatment when they felt pain, while the Non-Health group, which encompassed many individuals over 25 years, chose to perform tooth extractions.

Another aspect with a significant association within this block was the self-perception of bad breath, which was low in both groups and reported less frequently in the Health group. This fact may be due to the low incidence of smokers in the sample, as well as indicating greater oral hygiene care among the group members, since society requires, even as students, that future health professionals have a pleasant personal appearance. Within this context, studies among students in the non-health area and from 
private institutions, there observed a higher frequency of smokers, predominantly men, who considered their oral health poor and had greater dental needs $[4,6,10]$.

Private dental services were predominantly indicated as the place of the most recent appointment, corroborating previous findings $[3,4]$. Considering that the majority of the interviewees in the present study were aged up to 25 years old, a difference was observed with the result of a national survey for the group aged 15 to 19 years (where the majority claimed to have gone to public services), while there was a similarity with the data of adults (35-44 years) who attended private services more often [23]. It should be emphasized that in the northeast of Brazil there are often difficulties in accessing public dental services, leading to a migration of patients to private services.

Most students visited the dentist at least every six months, as observed in literature $[3,5,14]$ and in the results of a national epidemiological survey on oral health, where most of the adolescents interviewed stated that their most recent appointment had been within the last year [23]. It is important to highlight that some students, mainly from the "Non-Health" group, reported going to the dentist "only in case of pain", similar to other studies $[11,20]$. This finding is worrisome since oral pathologies in an advanced state can impact the general health of the individual, leading to death in extreme cases, requiring an awareness of the importance of regular visits to the dentist for diagnostic evaluations and preventive guidance.

Similar to the findings of other studies $[4,7,10,14]$, a high frequency of students reported gingival bleeding when brushing their teeth, and stated that they needed dental treatment, even though they had not suffered toothache in the previous six months. In the SB Brasil 2010 survey, dental morbidity was widely self-reported by young northeasterners and Brazilians, as well as the absence of pain in the last semester [23].

Regarding self-perception and impacts on oral health, most of the university students interviewed were satisfied with regard to their teeth and mouth. Considering the mean age of the sample, this level of satisfaction corroborates the data from the SB Brazil 2010 survey, where the majority in the 15 to 19 year old age group were satisfied, both regionally and nationally. The most prevalent impacts observed were those related to difficulty eating, embarrassment when smiling and being irritated or nervous, similar to SB Brasil 2010 for the adolescent age group [23].
One limitation of the present study is that, similar to other articles based on the self-reporting of oral health $[2,5,8,20]$, there was no normative evaluation of the oral cavity of the students for comparison with the oral health conditions reported. Future investigations should be carried out to assess whether this influence occurs among students in the final periods of their courses, combined with oral examinations that corroborate the self-reported information.

Addressing oral health during academic life is strongly evidenced in studies where teachers of the early years of education indicated that they had received little information on the subject in pedagogy degree courses [24]. Thus, there is a need to review training policies, seeking to improve the qualifications and knowledge of these professionals, who represent essential agents in health education programs and self-care, as schools are environments for acquiring and reinforcing good habits, while children, although at an age of risk in relation to oral health problems, are conducive to the adoption of educational and preventive measures [25].

Some negative aspects identified in the study (the high intake of sugar between meals, gingival bleeding, the seeking of treatment only in case of pain) express the need for awareness programs among university students, culminating in the acquisition and maintenance of good oral health. It is believed that with the recent inclusion, in 2018, of the dentistry course at the institution, the entire academic community will benefit through educational actions, as well as curative approaches, since a significant number of students reported needing treatment.

\section{CONCLUSION}

The area of undergraduate study was found to influence the source of information on oral health, the reason for seeking and the type of treatment, and the self-perception of bad breath, with the Health group reporting greater satisfaction with their oral health. The Health and Non-Health groups stated that they had received instruction on oral health, however a portion of the students demonstrated a lack of knowledge and poor practices, which can be reversed through strategic programs aimed at the academic community. 


\section{Collaborators}

DR FARIAS collaborated in the bibliographic research, data collection and analysis, and writing of the article. AMG OLIVEIRA, RB BRITO JUNIOR and L ZANIN collaborated in the critical review and writing of the article. FM FLORIO oversaw the conception, design and development of the study, assisted in data analysis, contributed to the final review and writing of the manuscript and participated in the final approval of the article.

\section{REFERENCES}

1. Pohjola V, Rekol A, Kunttu K, Virtanen Jl. Association between dental fear and oral health habits and treatment need among University students in Finland: a national study. BMC Oral Health. 2016;16-26. http://dx.doi.org/10.1186/s12903-0160179-y

2 Oliveira-Júnior JK, Barnabé LEG, Santos ML, Macedo A, Rodrigues RQF, Macena MCB. O valor atribuído à saúde bucal: um estudo com acadêmicos iniciantes de quatro cursos de graduação. Arch Health Invest. 2017;6(3):106-9. http:// dx.doi.org/10.21270/archi.v6i3.1828

3. Oro A, Zablaskas JM, Freddo SL, Zasso FM, Freddo AL. Hábitos alimentares e saúde bucal de estudantes de odontologia. Tecnol Rev Cient. 2015;3(2):7-29.

4. Freire MCM, Martins $A B$, Santos $C R$, Martins NO, Filizzola EM, Jordão LMR et al. Condição de saúde bucal, comportamentos, autopercepção e impactos associados em estudantes universitários moradores de residências estudantis. Rev Odontol UNESP. 2012;41(3):185-91.

5. Cruz MCC, Fernandes TC, Fernandes KGC, Kina M, Martins LO, Simonato LE. Práticas de higiene oral de graduandos de odontologia. Arch Health Invest. 2015;4(3): 52-56.

6. Pacheco TFF, Faria ALS, Rezende AC, Cozac FRD, Lima AA, Stefani CM. Influência do status tabágico na autopercepção de saúde bucal de Universitários. Rev Odontol Bras Central. 2014;23(64):24-9.

7. Souza CHC, Dantas-Neta NB, Laurentino JB, Santos DLN, Prado Junior RR, Mendes RF. Fatores de risco relacionados à condição de saúde periodontal em universitários. Rev Odontol UNESP. 2013;42(3):152-9. http://dx.doi.org/10.1590/S180725772013000300002

8. Taniguchi-Tabata A, Ekuni D, Mizutani S, Yamane-Takeuchi M, Kataoka K, Azuma T, Tomofuji T, Iwasaki Y, Morita M. Associations between dental knowledge, source of dental knowledge and oral health behavior in Japanese university students: A cross-sectional study. PLoS One. 2017 8;12(6):e0179298. http://dx.doi.org/10.1371/journal. pone.0179298

9. Dayakar MM, Kumar J, Pai GP, Shivananda H, Rekha R. A survey about awareness of periodontal health among the students of professional colleges in Dakshina Kannada District. J Indian Soc Periodontol. 2016;20(1):67-71. http:// dx.doi.org/10.4103/0972-124X.168487
10. Dhaifullah E, Al-Maweri SA, Al-Motareb F, Halboub E, Elkhatat E, Baroudi K, et al. Periodontal Health Condition and Associated Factors among University Students, Yemen. J Clin Diagn Res. 2015;9(12):ZC30-3. http://dx.doi.org/10.7860/ JCDR/2015/16435.6964

11. Walker KK, Jackson RD. Oral health beliefs and behaviors of nurse and nurse practitioner students using the HU-DBI inventory: An opportunity for oral health vicarious learning. J Nurs Educ Pract. 2017;7(8):19-26. http://dx.doi.org/10.5430/ jnep.v7n8p19

12. Rwakatema DS, Ananduni KN, Katiti VW, Msuya M, Chugulu J, Kapanda G. Oral health in nursing students at Kilimanjaro Christian Medical Centre teaching hospital in Moshi, Tanzania. BMC Oral Health. 2015;15:23. http://dx.doi.org/10.1186/ s12903-015-0008-8

13. Brasil. Ministério da Saúde. Secretaria de Políticas de Saúde. Departamento de Atenção Básica. Área Técnica de Saúde Bucal. Projeto SB2000: condições de saúde bucal da população brasileira no ano 2000: manual do coordenador [online]. Brasília: Ministério da Saúde, 2001 [citado 2016 out 12]. Disponível em: <https://www.nescon.medicina.ufmg.br/ biblioteca/imagem/1822.pdf>

14. Mariotto AH, Peralta FS, Fonseca FR, Aquino DR, Scherma AP. Avaliação dos hábitos de higiene bucal de alunos ingressantes no curso de odontologia da Universidade de Taubaté. Braz J Periodontol. 2015;25(3):26-34.

15. Roncalli AG, Silva NN, Nascimento AC, Freitas $\mathrm{CH}$, Casotti $E$, Peres $K G$, et al. Relevant methodological issues from the SBBrasil 2010 Project for national health surveys. Cad Saude Publica. 2012;28 Suppl:s40-57. http://dx.doi.org/10.1590/ S0102-311X2012001300006

16. Brasil. Ministério da Educação. INEP. Censo da Educação Superior 2016: Principais resultados [online]. Brasília: Ministério da Educação, 2017a [citado 2017 nov 27]. Disponível em: <http://download.inep.gov.br/educaca__ superior/censo_superior/documentos/2016/censo_superior_ tabelas.pdf>

17. Walsh T, Worthington HV, Glenny AM, Marinho VC, Jeroncic A. Fluoride toothpastes of different concentrations for preventing dental caries. Cochrane Database Syst Rev. 2019;3:CD007868. http://dx.doi.org/10.1002/14651858.CD007868.pub3

18. Creeth JE, Gallagher A, Sowinski J, Bowman J, Barrett K, Lowe S, Patel K, Bosma ML. The effect of brushing time and dentifrice on dental plaque removal in vivo. J Dent Hyg. 2009;83(3):111-6.

19. Brasil. Ministério da Saúde. Secretaria de Vigilância em Saúde. Departamento de Vigilância de Doenças e Agravos não Transmissíveis e Promoção da Saúde. Vigitel Brasil 2016: vigilância de fatores de risco e proteção para doenças crônicas por inquérito telefônico: estimativas sobre frequência e distribuição sociodemográfica de fatores de risco e proteção para doenças crônicas nas capitais dos 26 estados brasileiros e no Distrito Federal em 2016 [online]. Brasília: Ministério da Saúde, 2017b [citado 2017 out 27]. Disponível em: <http:// portalarquivos.saude.gov.br/images/pdf/2017/junho/07/ vigitel_2016_jun17.pdf> 
20. Bhattarai R, Khanal S, Rao GN, Shrestha S. Oral health related knowledge, attitude and practice among nursing students of Kathmandu - a pilot study. JCMS Nepal. 2016;12(4):160-8. http://dx.doi.org/10.3126/jcmsn.v12i4.15135

21. Jaber MF, Khan A, Elmosaad $Y$, Mustafa MM, Suliman $N$, Jamaan A. Oral health knowledge, attitude and practices among male Qassim university students. Int J Com Med Public Health. 2017;4(8):2729-35. http://dx.doi.org/10.18203/23946040.ijcmph20173316

22. Moura AMG, Bordin D, Fadel CB. O entendimento do processo saúde-doença e o valor atribuído aos dentes em uma análise comparativa entre formandos de Odontologia e Engenharia Civil da UEPG/PR. Rev Odontol UNESP. 2012;41(6):340-7. http://dx.doi.org/10.1590/\$1807-25772012000500008

23. Brasil. Ministério da Saúde. Secretaria de Atenção à Saúde. Departamento de Atenção Básica. Projeto SB Brasil 2010: pesquisa nacional de saúde bucal 2010: resultados principais [online]. Brasília: Ministério da Saúde, 2011 [citado 2017 out 27]. Disponível em: <http://bvsms.saude.gov.br/bvs/ publicacoes/pesquisa_nacional_saude_bucal.pdf >

24. Magalhães CR, Schneider AS, Bauer MS, Strack MH, Souza CLE, Rosário $P$, et al. Formação de professores e profissionais de saúde para a promoção da autorregulação em saúde na infância. Rev Educ PUC-Camp. 2018;23(3):425-37. https:// doi.org/10.24220/2318-0870v23n3a4137

25. Oliveira EL, Riatto SG, Vieira APSB, Carvalho G, Fonseca M, Guedes $V$, et al. A importância do nível de conhecimento dos professores de escola pública do ensino fundamental sobre saúde bucal - revisão de literatura. Rev Campo do Saber. 2018;5(4):2-16.

Received on: 14/9/2019

Final version resubmitted on: 17/12/2019

Approved on: 12/2/2020 